\title{
Felodipine $\beta$-cyclodextrin complex as an active core for time delayed chronotherapeutic treatment of hypertension
}

KUNAL P. PAGAR

PRADEEP R. VAVIA*

Department of Pharmaceutical Sciences and Technology, Institute of Chemical Technology, Mumbai, India

\begin{abstract}
The present research work deals with the development of a time delayed chronotherapeutic formulation of felodipine (FD) aimed at rapid drug release after a desired lag time in the management of hypertension. The developed system comprises a drug core embedded within a swellable layer and coated with an insoluble, water permeable polymeric system. FD cyclodextrin complex was used as an active core while ethyl cellulose was used as an effective coating layer. Dissolution studies of the complex revealed that there was a 3-fold increase in dissolution of the complex compared to plain FD. This dissolution enhancement and rapid drug release resulted from FD amorphisation, as confirmed by XRD, DSC and SEM studies. FTIR and ${ }^{1} \mathrm{H}$ NMR studies confirmed the complex formation between FD and cyclodextrin based on the observed hydrogen bond interactions. FD release was adequately adjusted by using a $\mathrm{pH}$ independent polymer, i.e., ethyl cellulose, along with dibutyl phthalate as plasticizer. Influence of formulation variables like polymer viscosity, plasticizer concentration, super disintegrant concentration in the swellable layer and percent coating weight gain was investigated to characterize the lag time. Upon permeation of water, the core tablet swelled, resulting in the rupture of the coating layer, followed by rapid drug release. The developed formulation of FD showed a lag time of 5-7 h, which is desirable for chronotherapeutic application.
\end{abstract}

Keywords: felodipine, $\beta$-cyclodextrin, chronotherapeutic, ethyl cellulose

The key to the success of any drug delivery system depends upon the development of formulations that accomplish the therapeutic needs associated with a particular pathological condition or disease state (1). Many physiological body functions (e.g., blood

\footnotetext{
*Correspondence; e-mail: pr.vavia@ictmumbai.edu.in, vaviapr@yahoo.com
} 
K. P. Pagar and P. R. Vavia: Felodipine $\beta$-cyclodextrin complex as an active core for time delayed chronotherapeutic treatment of hypertension, Acta Pharm. 62 (2012) 395-410.

pressure, hormonal levels) and pathophysiological disease states (e.g., hypertension, myocardial infarction, bronchial asthma and rheumatic disease) show a circadian pattern in their manifestations $(2,3)$. Therefore, the management of such disease states should preferentially involve delivery systems that release drugs after a specified delay period (lag period-time of no drug release) after dosing (4). Thus, drug release from the formulation will be targeted at a specific period of the day when there is a higher chance of clinical manifestation of the disease. Such delivery approach is termed chronotherapeutic (chronos - time) $(5,6)$.

Felodipine (FD), which is used in the proposed research, belongs to a category of dihydropyridine derivatives. It is chemically described as ethylmethyl-4-(2,3-dichlorophenyl)-1,4-dihydro-2,6-dimethyl-3,5-pyridine-carboxylate (7). FD is a calcium antagonist commonly used for its excellent antihypertension and antianginal effects $(7,8)$. FD is a poorly water-soluble drug belonging to the BCS class II drugs (9). Bioavailability of FD is strongly limited by its high lipophilic character (aqueous solubility $<0.5 \mathrm{mg} \mathrm{L}^{-1}$ ) (10). Efficient delivery of this poorly water-soluble drug was achieved by increasing its solubility, which resulted in dissolution enhancement. One of the methods used to increase the solubility of a poorly water-soluble drug is the cyclodextrin complexation technique $(11,12)$. The proposed mechanism by which this solubilisation occurs is the inclusion complex formation, in which there is dynamic equilibrium between the guest and host molecules with the complex $(13,14)$. Cyclodextrin complexation technology of FD would be an efficient, convenient, economical and industrially scalable approach for its dissolution enhancement.

FD is a typical example of a drug that can be used in the chronotherapeutic treatment of hypertension (15). Although many cardiovascular treatments are designed to give a constant effect throughout a 24-hour cycle, in most cases, the night time requirement is not the same as that during the day (16). For such cases, the delivery of cardiovascular agents using conventional dosage forms is inappropriate, since their administration just before the appearance of worse symptoms cannot be possible because of the sleeping cycle of patients. Hence, chronotherapeutic systems aimed at delayed drug release could be an optimal approach (17).

The aim of the present research work was to formulate a time delayed chronotherapeutic formulation of FD using a $\mathrm{pH}$ independent polymer as functional coating material. Different viscosity grades of ethyl cellulose, along with hydrophobic plasticizer, are used as functional coating material. Such a hydrophobic coating layer acts as an alarm clock, releasing the drug from the active core at a predictable time. Predictable time is the period during which there are maximum chances of ischemic heart diseases to occur, during the early morning hours or at night. Furthermore, dissolution enhancement of FD must be achieved for its immediate and complete release. This cyclodextrin complexation technology, which is the simplest and most economical approach for dissolution enhancement of poorly water-soluble drugs, was used and characterized extensively to confirm the inclusion complex formation. 
K. P. Pagar and P. R. Vavia: Felodipine $\beta$-cyclodextrin complex as an active core for time delayed chronotherapeutic treatment of hypertension, Acta Pharm. 62 (2012) 395-410.

\section{EXPERIMENTAL}

\section{Materials}

Felodipine was obtained from Nivedita Chemicals Pvt. Ltd. (India). Dibutyl phthalate was purchased from Merck (India). $\beta$-cyclodextrin ( $\beta$-CD), different grades of ethyl cellulose, Ac-di-sol, directly compressible lactose, aerosil, magnesium stearate and talc were obtained from Signet Chemical Corp. Pvt. Ltd. (India). Solvents such as methylene chloride and isopropyl alcohol were purchased from Merck. All other chemicals and reagents were of analytical grade. Distilled water was used throughout the study.

\section{Preparation of inclusion complex}

The inclusion complex was prepared by the method of kneading. $\beta$-CD (3.24 g) was placed in a mortar, wetted with absolute ethanol and kneaded upto paste consistency. FD (1.091 g) was added and kneaded $60 \mathrm{~min}$ with successive addition of absolute ethanol. The formed complex was dried at $40{ }^{\circ} \mathrm{C}$ for $4 \mathrm{~h}$. The dried powder was passed through a $60 \#$ sieve and stored in a desiccator to get constant mass.

\section{Preparation of physical mixture}

Equal mole amounts of FD and $\beta-C D$ were mixed thoroughly in the dry state. The mixture was passed through a 60\# sieve and stored in a desiccator.

\section{Phase solubility studies}

The phase solubility study was conducted according to the Higuchi and Connors method (18). In brief, an excess amount of FD was added to stoppered conical flasks containing aqueous solution $(25 \mathrm{~mL})$ of various $\beta$-cyclodextrin concentrations $\left(0-15 \mathrm{mmol} \mathrm{L}^{-1}\right)$. The suspensions were shaken for $24 \mathrm{~h}$ at $37^{\circ} \mathrm{C}$ on a shaker rotating at $200 \mathrm{rpm}$ (Orbital Shaker Incubator, Remi Laboratory Instruments, India). Equilibrated aliquots were filtered through a $0.22-\mu \mathrm{m}$ nylon filter (Millipore, India) and analyzed by UV spectrophotometrically at $362 \mathrm{~nm}$ (Jasco V-530, Japan). The stability constant (K) for FD/ $\beta-C D$ was calculated, using the equation:

$$
K=\text { Slope } / S(1-\text { Slope })
$$

where, $S$ is solubility of FD in the absence of $\beta-C D$.

\section{Characterization of the inclusion complex}

Differential scanning calorimetry (DSC). - Thermal characterization of the complex was done using a differential scanning calorimeter (Perkin Elmer, Pyris-6 DSC, USA). Alumina was used as reference material and the analysis was carried out in a nitrogen atmosphere $\left(20 \mathrm{~mL} \mathrm{~min}{ }^{-1}\right)$. All samples were run at a scanning rate of $10{ }^{\circ} \mathrm{C} \mathrm{min}-1$ from 30 to $250{ }^{\circ} \mathrm{C}$. 
K. P. Pagar and P. R. Vavia: Felodipine $\beta$-cyclodextrin complex as an active core for time delayed chronotherapeutic treatment of hypertension, Acta Pharm. 62 (2012) 395-410.

Powder X-ray diffractometry (PXRD). - The study was carried out using an X-ray diffractometer (Rigakuminiflex, Japan). Radiation was from Ni filtered CuK, with a wavelength of $0.154 \mathrm{~nm}$ having a graphite monochromator. Scanning range was 0-70 with a scanning rate of $2 \mathrm{~min}^{-1}$.

Fourier transform infrared (FTIR) spectroscopic analysis. - FTIR spectra of powder samples were recorded on a FTIR-5300 spectrophotometer (Jasco, Japan) by the KBr disk method using a hydrostatic press to form a compact disc of samples. The scanning range was $4,000-400 \mathrm{~cm}^{-1}$.

${ }^{1} \mathrm{H}$ NMR spectroscopy. - The ${ }^{1} \mathrm{H}$ NMR spectra of different powder samples were recorded using a Mercury Plus $300 \mathrm{MHz}$ NMR spectrometer (Varian, USA). The spectra were recorded in deuterated water $\left(\mathrm{D}_{2} \mathrm{O}\right)$ solvent systems.

Microscopic examination. - Powder samples of FD, $\beta-C D$, physical mixture of FD: $\beta$-CD and the kneaded complex thereof were subjected to microscopic analysis using a scanning electron microscope (SEM) (Hitachi, Japan).

In vitro dissolution studies. - In vitro dissolution of plain FD, physical mixture and the complex were carried out using a USP Type II (paddle) apparatus (Electrolab, India). Dissolution of powders equivalent to $10 \mathrm{mg}$ of FD was studied in water, in $6.5 \mathrm{pH}$ buffer with surfactant (Tween 20, $2 \%, m / V)$. Dissolution medium $(500 \mathrm{~mL}$ ) was taken and maintained at $37 \pm 0.5{ }^{\circ} \mathrm{C}$. The paddles were rotated at $50 \mathrm{rpm}$. Samples were withdrawn at different time intervals, filtered through Whatman filter paper, and analyzed for percent drug released spectrophotometrically at $362 \mathrm{~nm}$ (19).

\section{Tablet formulation}

Formulations of core tablets were designed as shown in Table I. All the ingredients were weighed accurately and passed through a $40 \#$ sieve to prevent segregation while mixing. Optimized and dried FD/ $\beta-C D$ complex was mixed with the excipients in geometric proportion to ensure uniform distribution. Furthermore, this blend was passed through a 60\# sieve. Compression was done on a 16 station rotary tablet press (Cadmach, India) using $7 \mathrm{~mm}$ round standard concave punches to a hardness of $5-6 \mathrm{~kg} \mathrm{~cm}^{-2}$.

\section{Coating of tablets}

Prepared tablet cores of various batches, as shown in Table I, were subjected to coating with a non-aqueous coat of $5 \%(\mathrm{~m} / \mathrm{V})$ ethyl cellulose in a mixture of dichloromethane/isopropylalcohol (1:1) at pan speed of $32 \mathrm{rpm}$. Dibutyl phthalate was added into the polymeric solution in weight percent of polymer concentration in order to form a good, intact and flexible polymeric film. Automized air was maintained at a flow rate of $450 \mathrm{mg} \mathrm{min}^{-1}$ and with $1.5 \mathrm{~kg} \mathrm{~cm}^{-2}$ air pressure.

\section{Effect of formulation variables}

As shown in Table I, different batches were designed with variations in decisive formulation variables such as polymer viscosity, plasticizer concentration, super disinte- 
K. P. Pagar and P. R. Vavia: Felodipine $\beta$-cyclodextrin complex as an active core for time delayed chronotherapeutic treatment of hypertension, Acta Pharm. 62 (2012) 395-410.

Table I. Different tablet batches containing FD/ $\beta-C D$ complex coated with ethyl cellulose

\begin{tabular}{lcccccccccccc}
\hline Ingredients (mg) & F1 & F2 & F3 & F4 & F5 & F6 & F7 & F8 & F9 & F10 & F11 & F12 \\
\hline FD/ $\beta$-CD complex & 39.53 & 39.53 & 39.53 & 39.53 & 39.53 & 39.53 & 39.53 & 39.53 & 39.53 & 39.53 & 39.53 & 39.53 \\
DC lactose & 85.47 & 85.47 & 85.47 & 85.47 & 85.47 & 85.47 & 92.47 & 89.47 & 80.47 & 85.47 & 85.47 & 85.47 \\
Ac-di-sol & 10.00 & 10.00 & 10.00 & 10.00 & 10.00 & 10.00 & 3.00 & 6.00 & 15.00 & 10.00 & 10.00 & 10.00 \\
Talc & 1.00 & 1.00 & 1.00 & 1.00 & 1.00 & 1.00 & 1.00 & 1.00 & 1.00 & 1.00 & 1.00 & 1.00 \\
Mg stearate & 2.00 & 2.00 & 2.00 & 2.00 & 2.00 & 2.00 & 2.00 & 2.00 & 2.00 & 2.00 & 2.00 & 2.00 \\
Aerosil & 2.00 & 2.00 & 2.00 & 2.00 & 2.00 & 2.00 & 2.00 & 2.00 & 2.00 & 2.00 & 2.00 & 2.00 \\
Coat & & & & & & & & & & & & \\
$\begin{array}{l}\text { Ethyl cellulose } \\
\text { (7 Pa s) }\end{array}$ & 10.50 & 10.50 & 10.50 & 10.50 & 10.50 & 10.50 & 10.50 & 10.50 & 10.50 & 3.50 & 7.00 & 14.00 \\
$\begin{array}{l}\text { Dibutyl phthalate } \\
\text { \%, } m / m)\end{array}$ & 12.50 & 12.50 & 12.50 & 0 & 5.00 & 10.00 & 12.50 & 12.50 & 12.50 & 12.50 & 12.50 & 12.50 \\
Mass gain (\%) & 7.50 & 7.50 & 7.50 & 7.50 & 7.50 & 7.50 & 7.50 & 7.50 & 7.50 & 2.50 & 5.00 & 10.00 \\
\hline
\end{tabular}

a ethyl cellulose (10 Pa s), b ethyl cellulose (22 Pa s), DC - directly compressible, Ac-di-sol - croscarmellose sodium, Aerosil - silicon dioxide

grant concentration and weight gain of the core tablet. Optimization of these parameters plays a crucial role for attaining the desired drug release profile, essential for the chronotherapeutic application of the drug. All these formulation factors were varied to study their effect on in vitro release of the drug and to achieve the desired lag time of 5-7 hours, necessary to meet the therapeutic requirement of delayed release. Three different grades of ethyl cellulose were used to coat the tablet core. Ethyl cellulose N7, ethyl cellulose N10 and ethyl cellulose N22 were different grades of the polymer corresponding to their respective viscosity of 7,10 and $22 \mathrm{~Pa}$ s. Dibutyl phthalate, one of the commonly used hydrophobic plasticizers, was added to impart flexibility to ethyl cellulose film. Tablet cores were coated with the polymeric solution containing different concentrations of dibutyl phthalate ranging from 0 to $12.5 \%(\mathrm{~m} / \mathrm{m})$ (plasticizer mass with respect to polymer mass). Such coated tablets were evaluated for their effect on in vitro release of FD. Different batches with wide-ranging concentrations of superdisintegrant, Ac-di-sol, viz. 3, 6, 10 and $15 \mathrm{mg}$, were taken to study their effect on the lag time and subsequent drug release profile. Batches with different coating mass gain were prepared and evaluated for their in vitro release behaviour. Effect of these decisive formulation variables on in vitro drug release were studied by carrying out dissolutionin $6.5 \mathrm{pH}$ buffer with $2 \%$ surfactant (Tween-20). In order to simulate GIT conditions in vivo, drug release was also carried out in sequential buffer change, i.e., $1.2 \mathrm{pH}$ buffer $(0-2 \mathrm{~h}), 4.5 \mathrm{pH}$ buffer $(2-4 \mathrm{~h})$ and in $6.5 \mathrm{pH}$ buffer with $2 \%$ surfactant ( $4 \mathrm{~h}$ onwards). These dissolution studies were carried out in $500 \mathrm{~mL}$ of medium using the USP Type II dissolution apparatus. Drug release was determined spectrophotometrically at $362 \mathrm{~nm}$. During the dissolution experiment, a rupture test was performed, which was based on visual observations and drug release data. The rupture test gave an idea about the time taken for the coat to rupture, i.e., lag time. 


\section{RESULTS AND DISCUSSION}

Phase solubility studies confirmed the solubility enhancing capacities of $\beta-C D$, as shown in Fig. 1. Aqueous solubility of FD increased as a function of $\beta$-CD concentration. Solubility curve obtained was classified as AL type, indicating 1:1 molar stoichiometry of the complex. Stability constant calculated from the slope and intercept of the solubility curve was found to be $185.5 \mathrm{~L} \mathrm{~mol}^{-1}$. The kneading method was used for the formation of the inclusion complex of FD with $\beta-C D$ at a molar ratio 1:1.

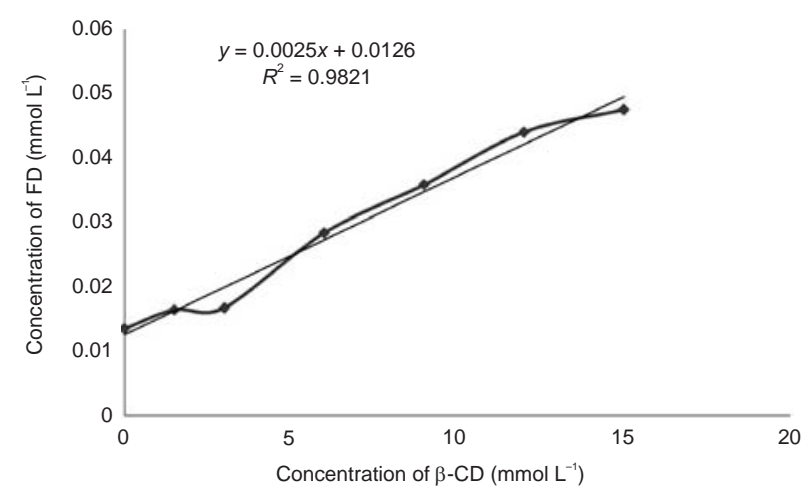

Fig. 1. Phase solubility diagram of felodipine with increasing $\beta-C D$ concentration.

Based on the literature, it was shown that inclusion complexes of the poorly water-soluble drug with cyclodextrins were formed in non-covalent manner, without chemical bonds. Hydrophobic interactions and van der Waals bonds are mainly involved in their formation. Thus, identification of this inclusion complex phenomenon was done using DSC, PXRD, FTIR and SEM. As shown in Fig. 2, FD showed an endotherm at $149{ }^{\circ} \mathrm{C}$ corresponding to the melting point of the drug, and the curve of $\beta-C D$ showed a broad endotherm at $102{ }^{\circ} \mathrm{C}$ owing to the release of water molecules residing in the cavity. Comparing the DSC curves of FD, $\beta-C D$, physical mixture and the formed complex, it was found that the curve of the physical mixture showed two endotherms at 145 and $111^{\circ} \mathrm{C}$ with almost significant intensity compared to that of FD and plain $\beta-C D$, respectively, whereas the curve of the complex showed endotherms with diminished intensity, indicating formation of a new solid state owing to the inclusion complex phenomenon. In addition, the characteristic endothermic effect of $\beta-C D$ was slightly shifted to higher temperature, indicating that FD had complexed with $\beta$-CD. In fact, even though not unambiguously attributable to inclusion complexation, this phenomenon is indicative of a stronger interaction between the drug and $\beta-C D$ in the solid state $(20,21)$.

The PXRD patterns of FD, $\beta-C D$, physical mixture of FD: $\beta-C D$ and their complex are shown in Fig. 3. Sharp and intense peaks observed in the diffractogram for FD indicate a crystalline nature of the drug. The PXRD pattern of the complex was diffused and 
K. P. Pagar and P. R. Vavia: Felodipine $\beta$-cyclodextrin complex as an active core for time delayed chronotherapeutic treatment of hypertension, Acta Pharm. 62 (2012) 395-410.

a)
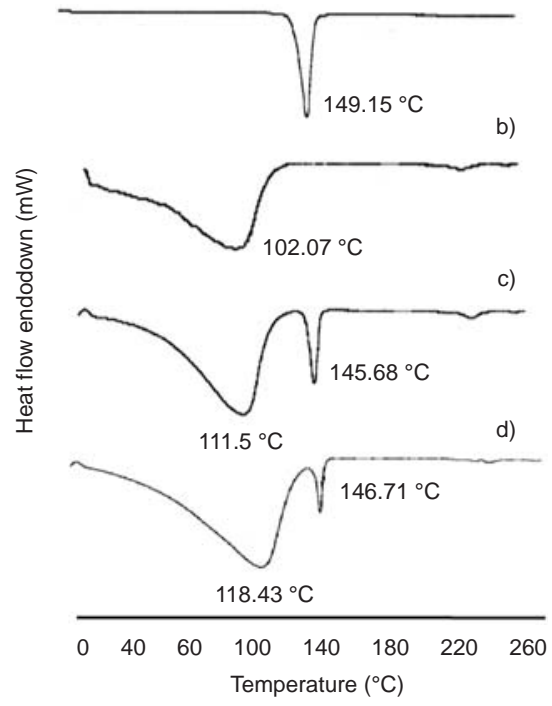

Fig. 2. DSC thermograms of: a) felodipine, b) $\beta$-cyclodextrin, c) physical mixture and d) complex.

different from that of the plain drug and physical mixture, confirming the formation of a new solid phase, which had an amorphous nature. Prominent peaks of FD either disappeared or were less intense in the complex form (Table II), suggesting a strong interaction between the drug and $\beta$-cyclodextrin. Despite the fact that the PXRD diffractogram

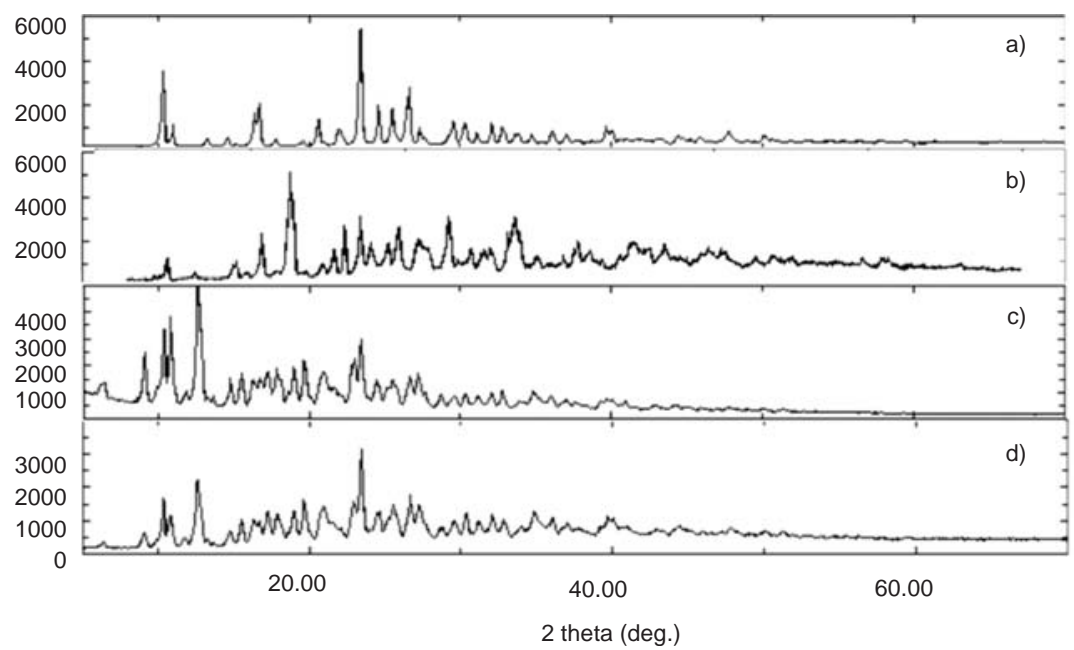

Fig. 3. XRD Patterns of: a) felodipine, b) $\beta$-cyclodextrin, c) physical mixture and d) complex. 
K. P. Pagar and P. R. Vavia: Felodipine $\beta$-cyclodextrin complex as an active core for time delayed chronotherapeutic treatment of hypertension, Acta Pharm. 62 (2012) 395-410.

Table II. Shifts in the XRD pattern of felodipine

\begin{tabular}{cccc}
\hline \multirow{2}{*}{$2 \theta$ (deg.) } & Drug $\left(I_{\mathrm{o}}\right)$ & Kneaded complex $\left(I_{\mathrm{c}}\right)$ & Relative degree of crystallinity $\left(I_{\mathrm{c}} / I_{\mathrm{o}}\right)$ \\
\cline { 4 - 4 } & 2113 & 510 & Kneaded complex \\
20.3 & 2315 & 1089 & 0.24 \\
23.5 & 5477 & 2095 & 0.47 \\
24.6 & 1998 & 1317 & 0.38 \\
25.5 & 1835 & 1210 & 0.65 \\
\hline
\end{tabular}

of the solid complex showed a characteristic pattern corresponding to the crystalline drug, the peak intensities were reduced, indicating a decrease in drug crystallinity. This decrease in drug crystallinity was responsible for the increased solubility of the solid complex compared to that of the pure drug. This phenomenon of increase in solubility with decrease in drug crystallinity has been reported in literature $(22,23)$.

The solid state interaction between cyclodextrin and the drug molecule was done using Fourier transform infrared (FT-IR) spectroscopy. Chemical interaction between the drug and the carrier often leads to identifiable changes in the infrared (IR) profile of complexes (24). In case of any interactions, the principal peaks pertaining to the various

.
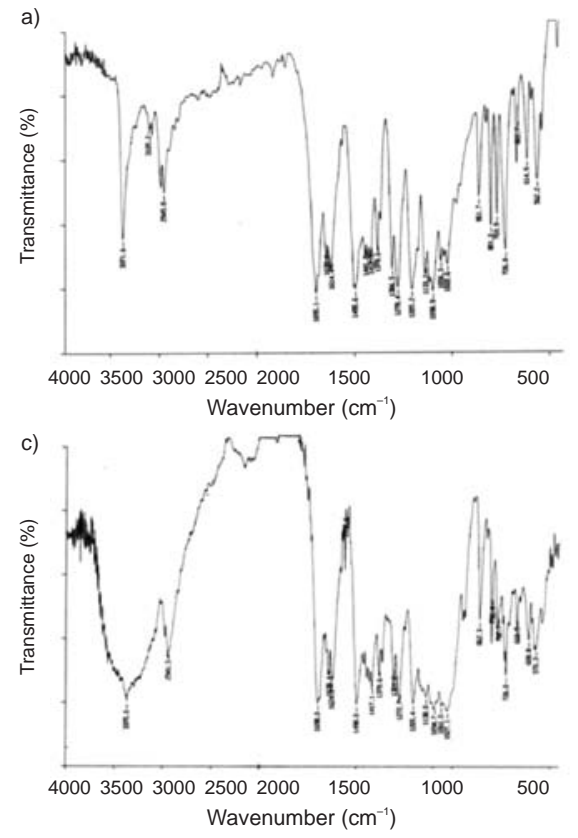
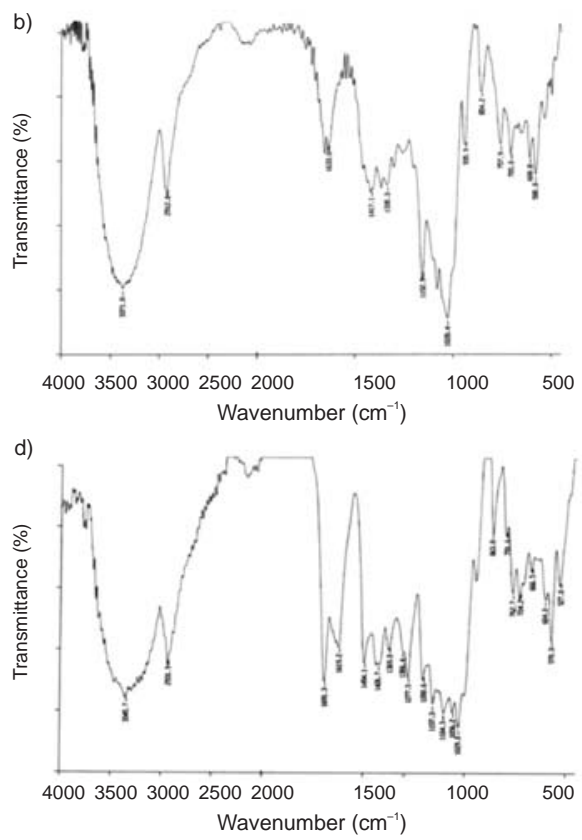

Fig. 4. FTIR spectra of: a) felodipine, b) $\beta$-cyclodextrin, c) physical mixture and d) complex. 
functional groups present in the guest molecule may be affected (25). IR spectral studies may also be indicative of the hydrogen bonding phenomenon that may be occurring between the guest and the host. Principal peaks corresponding to the structural features of FD were found due to N-H stretching at 3371.6, aliphatic C-H stretching at $2949.8 \mathrm{C}=\mathrm{O}$ ester group at 1695.1 and $\mathrm{C}-\mathrm{Cl}$ stretching at $726.8 \mathrm{~cm}^{-1}$, as shown in Fig. 4. The FT-IR spectrum of $\beta$-CD was characterized by a single broad band at $3300-3500 \mathrm{~cm}^{-1}$ due to $\mathrm{O}-\mathrm{H}$ stretching vibrations. Vibrations of the $\mathrm{C}-\mathrm{H}$ and $\mathrm{CH}_{2}$ groups appeared in the $2800-3000 \mathrm{~cm}^{-1}$ region. Any sign of interaction would be reflected in changes of the characteristic peak of FD, depending on the extent of interaction. Principal peaks corresponding to FD were affected. Changes in the characteristic bands of FD in the complex like $\mathrm{N}-\mathrm{H}$ stretching at 3345.7, aliphatic C-H stretching at 2931.9 and $\mathrm{C}=\mathrm{O}$ ester group at $1690.3 \mathrm{~cm}^{-1}$ confirm the interaction of the drug with cyclodextrin. Thus, IR studies showed that the aromatic functional group of FD interacted with the O-H group of cyclodextrins through hydrogen bonding.

${ }^{1} \mathrm{H}$ NMR is an ideal tool to characterize the inclusion complex formation between the guest and the cyclodextrin cavity in the solution state. Proton chemical shifts and their variation between the free and complexed forms are reported in Table III, according to the numbering given in Fig. 5.
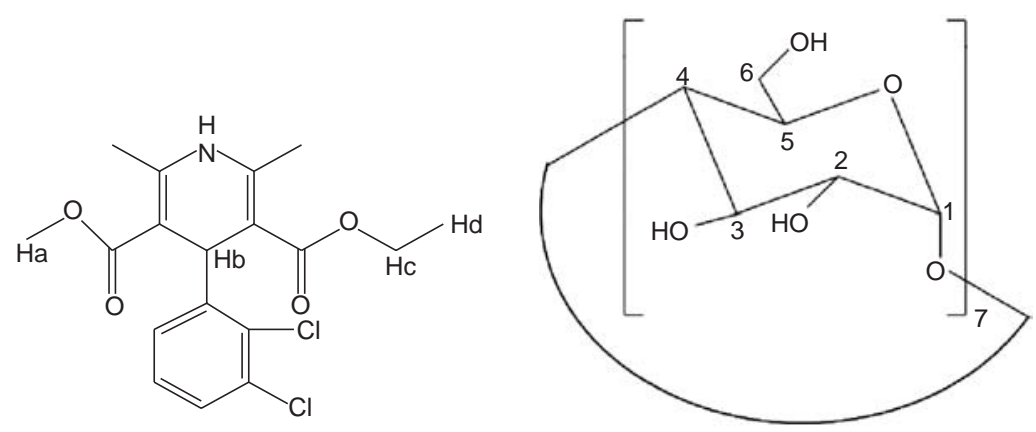

Fig. 5. Chemical structure of felodipine and $\beta$-cyclodextrin.

If a guest is incorporated into the cyclodextrin cavity, the hydrogen atoms located in the interior of the cyclodextrin cavity (H-3 and $\mathrm{H}-5)$ will be considerably shielded by the guest molecule, causing a significant upfield shift whereas the protons on the exterior surface of the torus (H-1, H-2, H-4 and H-6) will either be unaffected or experience a marginal shift. Alternately, if association takes place at the exterior of the torus (surface interaction), H-1, H-2, H-4 and H-6 will be strongly shielded (12). The H-3 triplet of $\beta$-CD appears at $\delta 3.891$ along with $\mathrm{H}-5$ and $\mathrm{H}-6$ at $\delta 3.822$ and 3.808, respectively. Complexation of FD with $\beta$-CD causes upfield shifts of the $\beta$-CD spectrum; however, the upfield shifts are not the same for all protons. H-3 signal of $\beta-C D$ shows strong upfield shifts of about -0.019 ppm. The upfield shifts observed for $\mathrm{H}-3$ and $\mathrm{H}-5$ protons confirm the inclusion inside the cavity. Further confirmation is obtained by following the chan- 
K. P. Pagar and P. R. Vavia: Felodipine $\beta$-cyclodextrin complex as an active core for time delayed chronotherapeutic treatment of hypertension, Acta Pharm. 62 (2012) 395-410.

Table III. ${ }^{1} \mathrm{H}$ NMR chemical shifts for the protons of felodipine and $\beta$-cyclodextrin in the free state and in the inclusion complex

\begin{tabular}{cccc}
\hline \multirow{2}{*}{ Protons } & \multicolumn{3}{c}{$\delta(\mathrm{ppm})$} \\
\cline { 2 - 4 } & free & complex & $\Delta \delta$ \\
\hline Felodipine & 3.770 & 3.776 & +0.006 \\
$\mathrm{H}_{\mathrm{a}}$ & 4.780 & 4.972 & +0.192 \\
$\mathrm{H}_{\mathrm{b}}$ & 4.200 & 4.960 & +0.720 \\
$\mathrm{H}_{\mathrm{c}}$ & 1.29 & 1.047 & -0.243 \\
$\mathrm{H}_{\mathrm{d}}$ & & & \\
$\beta$-cyclodextrin & 3.913 & 3.894 & -0.019 \\
$\mathrm{H}-3$ & 3.534 & 3.533 & -0.001 \\
$\mathrm{H}-4$ & 3.822 & 3.830 & +0.006 \\
$\mathrm{H}-5$ & 3.808 & 3.815 & +0.007 \\
$\mathrm{H}-6$ & & & \\
\hline
\end{tabular}

ges in the chemical shifts for FD protons. The $\mathrm{H}_{\mathrm{a}}, \mathrm{H}_{\mathrm{b}}$ and $\mathrm{H}_{\mathrm{c}}$ protons of FD showed strong downfield shifts, confirming the formation of a complex between FD and $\beta-C D$.

The scanning electron micrograph, as shown in Fig. 6, indicated that drug particles had a more crystalline nature while the paste complex formed appeared in a different physical form, which seemed to be amorphous.
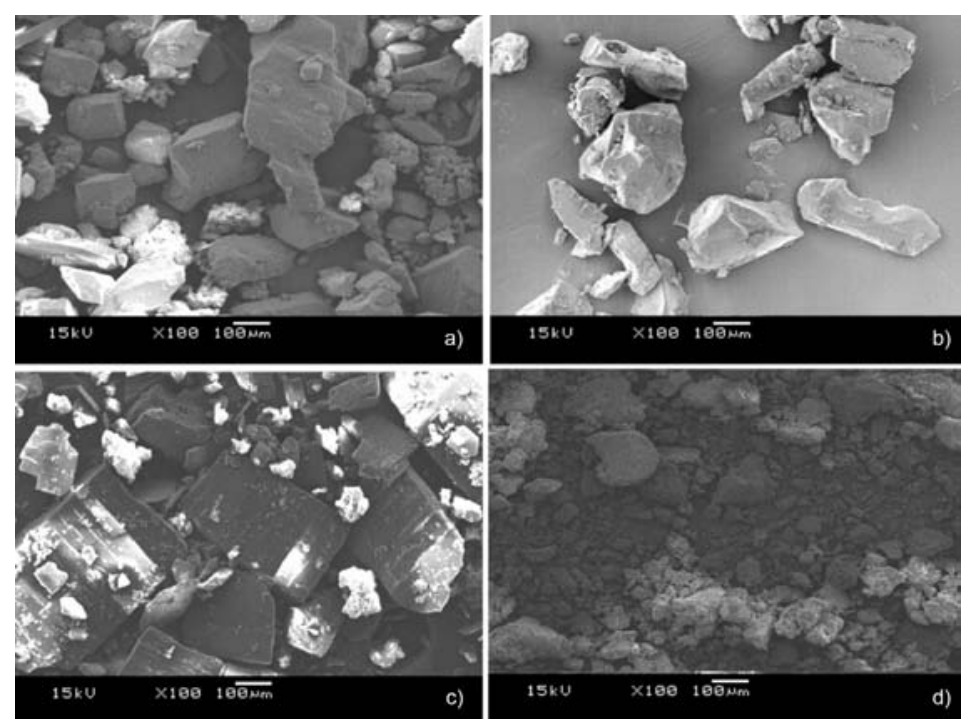

Fig. 6. SEM images of: a) felodipine, b) $\beta$-cyclodextrin, c) physical mixture and d) complex. 
K. P. Pagar and P. R. Vavia: Felodipine $\beta$-cyclodextrin complex as an active core for time delayed chronotherapeutic treatment of hypertension, Acta Pharm. 62 (2012) 395-410.

It is clear from the dissolution profiles that FD showed poor dissolution in distilled water with only $5 \%$ release in the first $10 \mathrm{~min}$, as shown in Fig. 7. Its physical mixture with $\beta$-CD provided no significant enhancement in drug dissolution. Inclusion complexation with $\beta$-cyclodextrin greatly improved the dissolution of FD, with $25 \%$ of the drug being dissolved within the first $10 \mathrm{~min}$. Thus, the complex formed showed a 4 -fold increase in drug dissolution in water. This was due to increased solubility and rapid wettability of the complexed drug. As shown in Fig. 7, plain FD gave a poor dissolution profile in $6.5 \mathrm{pH}$ buffer with surfactant. Its physical mixture with $\beta$-CD showed a very slight improvement in drug solubility. Dissolution studies of the complex revealed that approximately $90 \%$ of FD was released within the first 30 minutes in dissolution medium compared to plain FD (30\% in $30 \mathrm{~min}$ ), which is desirable for rapid drug release. Hence, the $\mathrm{FD} / \beta$-CD complex showed an approximately 3 -fold increase in drug dissolution with respect to plain FD. This was due to improved wettability of the drug, which resulted in significant improvement in drug solubility.
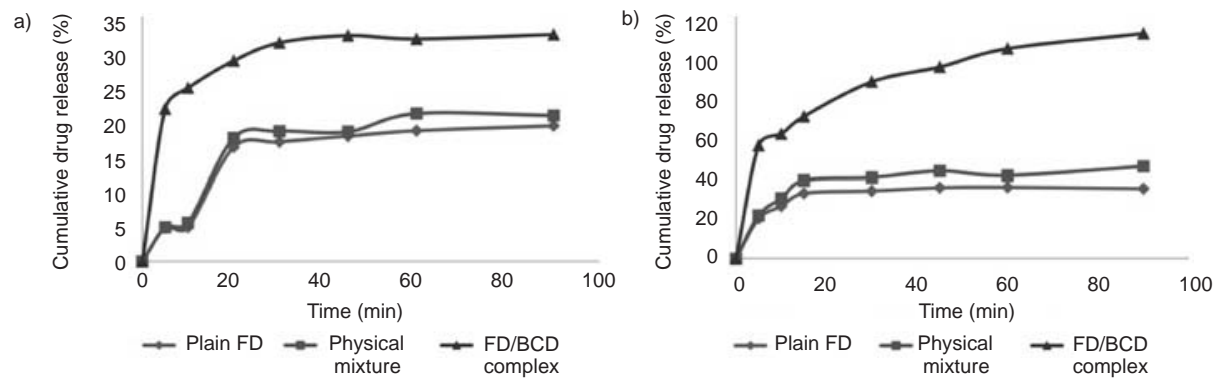

Fig. 7. Comparative plot of cumulative drug release vs. time: a) in distilled water, b) in $6.5 \mathrm{pH}$ buffer with surfactant (Tween-20).

Different formulation variables play a crucial role in optimization of the desired delayed drug release profile to meet the therapeutic requirement of the disease. Ethyl cellulose was chosen as the coating polymer because of its weak mechanical strength and insolubility throughout the gastrointestinal tract. Though a not very flexible film is desired, the film formed must be strong enough to withstand in vivo GIT turbulences and remain intact for the period of lag time. Therefore, various grades of ethyl cellulose differing in viscosity were screened. Effect of these grades on the in vitro drug release profile of FD is shown in Fig. 8. From the in vitro release behaviour, it can be concluded that as the viscosity of the polymer increased, stronger and more durable films were formed. The grade with the lowest viscosity (ethyl cellulose N7) showed good mechanical strength to resist the developing swelling pressure and to rupture after the desired lag time. Plasticizer also played a vital role in the formation of a tough and flexible film of the hard or brittle polymer. As shown in Fig. 8, a significant effect was observed on the lag time of ethyl cellulose coated tablet as the plasticizer concentration was changed. From the outcome of the drug release profiles, we can conclude that as the plasticizer concentration is increased, lag time will increase as well. Films plasticized with only $5 \%$ dibutyl 
phthalate were too brittle and ruptured before the desired lag time. For tablets with $10 \%$ plasticizer, films were somewhat rigid and ruptured leaving only small fissures as pathways for drug release. Tablets coated with films containing $12.5 \%$ plasticizer ruptured at the edge of the tablet upon swelling and left a wide orifice, from which almost all tablet core contents were released and only empty coating remained.
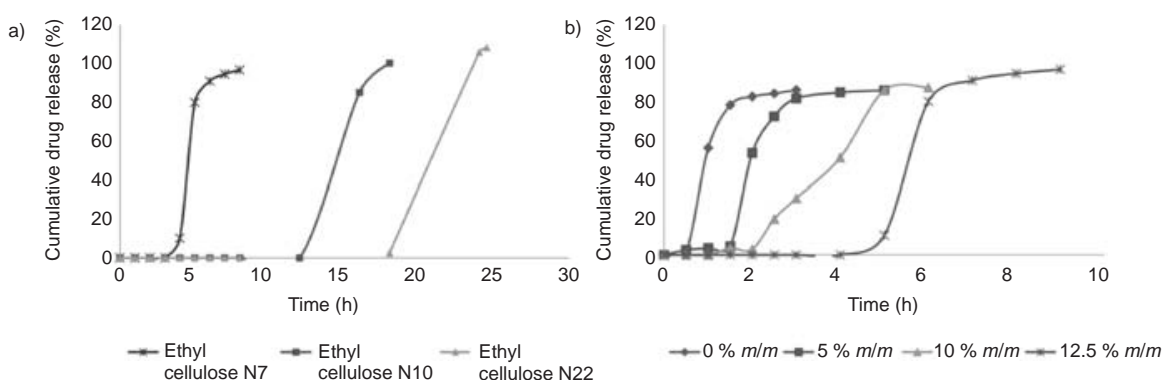

Fig. 8. a) Effect of different grades of ethyl cellulose on lag time and in vitro release profile; b) effect of different plasticizer concentrations on lag time and in vitro release profile.

The presence of superdisintegrant in tablet cores was crucial to create the pressure on the coating layer. Superdisintegrant swelling after the ingress of water into the tablet was a key factor for the rupture of ethyl cellulose coating. As the superdisintegrant concentration increased in the core, the lag time of core rupture decreased, as seen in Fig. 9.

a)

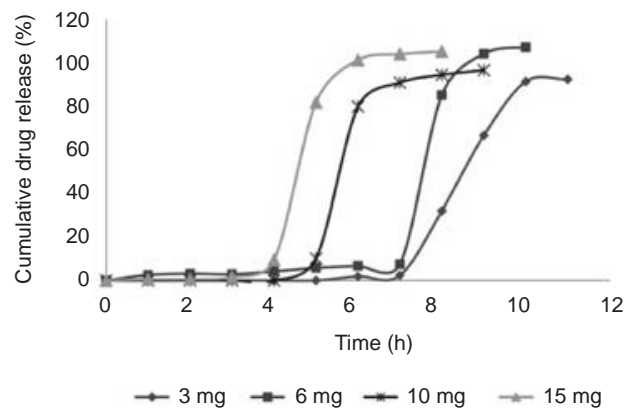

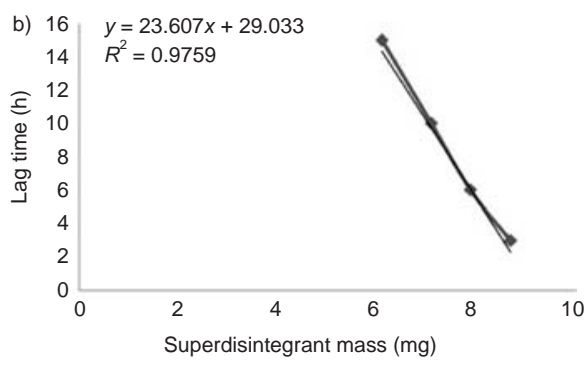

Fig. 9. a) Effect of superdisintegrant mass on lag time and in vitro profile; b) semi-logarithmic plot of superdisintegrant mass vs. lag time.

Increase in superdisintegrant concentration increased the water uptake of the core. This added to a rapid increase in core swelling. Such expanding core could now exert a greater amount of pressure on the coat, causing it to rupture more rapidly. The semi-logarithmic plot of superdisintegrant mass against time lag (Fig. 9) showed a good linear re- 
lationship $\left(R^{2}=0.975\right)$, indicating that this factor played a crucial role in the modulation of lag time. Increase in coat thickness also caused resistance to water penetration and coat rupture. As revealed in Fig. 10, with the increase of coat thickness, there was a corresponding increase in the lag time and subsequent drug release. Thus, percent coating mass gain was found to be another crucial parameter in the modulation of lag time and in achieving the desired drug release profile. The semi-logarithmic plot of percentage ethyl cellulose mass gain against lag time showed a good linear relationship, as shown in Fig. $10\left(R^{2}=0.992\right)$ indicating the vitality of this factor in lag time modulation.

a)

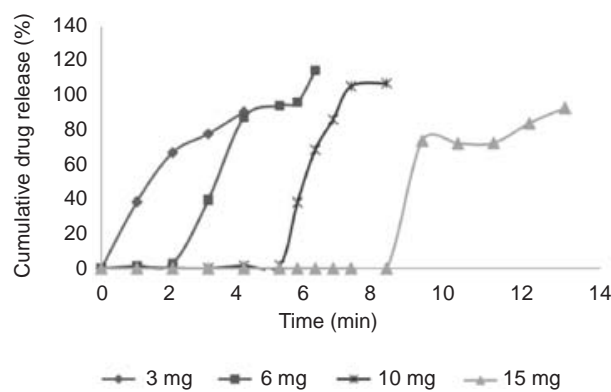

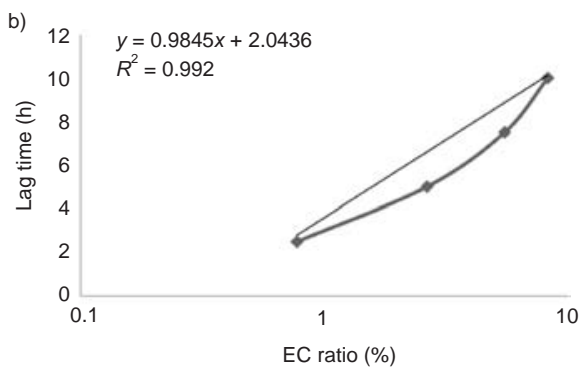

Fig. 10. a) Effect of percent coating mass gain on lag time and in vitro release profile; b) semi-logarithmic plot of percent ethyl cellulose mass gain vs. lag time.

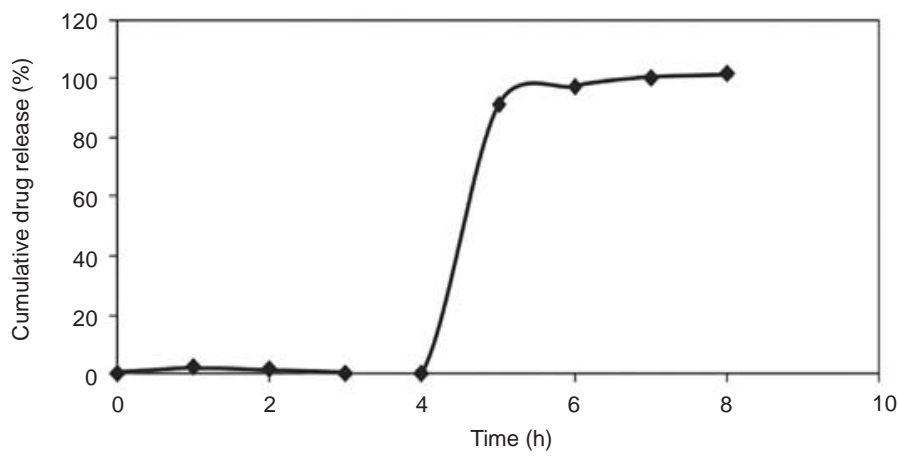

0-2 h; Buffer $\mathrm{pH} 1.2,2-4 \mathrm{~h}$ : Buffer $\mathrm{pH} 4.5$, from $4 \mathrm{~h}$ : Buffer with surfactant $\mathrm{pH} 6.5$

Fig. 11. Dissolution of optimized batch in sequential buffer change.

$\mathrm{pH}$ independent drug release behaviour of the polymer was also studied by carrying out dissolution in sequential buffer change. As shown in Fig. 11, drug release behaviour of the optimized formulation was found to be unaffected by the $\mathrm{pH}$ of the medium. Thus, the developed formulation showed a $\mathrm{pH}$ independent release profile of FD owing to the use of ethyl cellulose as hydrophobic functional coating material. 
K. P. Pagar and P. R. Vavia: Felodipine $\beta$-cyclodextrin complex as an active core for time delayed chronotherapeutic treatment of hypertension, Acta Pharm. 62 (2012) 395-410.

\section{CONCLUSIONS}

The most significant issue to consider when formulating chronotherapeutic delivery is to release the drug after a defined delay period (lag period-interval of no drug release) after being taken by the patient. Delayed release tablets with the felodipine $\beta$-cyclodextrin complex as a core and rupturable hydrophobic ethyl cellulose coating were developed. Complexation technology enhanced rapid release of the drug while the hydrophobic polymer coating aided in achieving the desired delayed release. Thus, targeting drug release at a specific time of the day, when there is maximal clinical manifestation of the disease, was achieved.

Acknowledgment. - The authors are grateful to the University Grant Commission (UGC), Government of India, for financial assistance and AICTE for providing facilities to perform the experimental work.

\section{REFERENCES}

1. B. Lemmer, Circadian rhythms and drug delivery, J. Control. Release 16 (1991) 63-74; DOI: 10.1016/ 0168-3659(91)90031-8.

2. T. Bussemer, I. Otto and R. Bodmeier, Pulsatile drug delivery systems, Crit. Rev. Ther. Drug. 18 (2001) 433-458.

3. T. Bussemer, A. Dashevsky and R. Bodmeier, A pulsatile drug delivery system based on rupturable coated hard gelatin capsules, J. Control. Release 93 (2003) 331-339; DOI: 10.1016/i.jconrel. 2003.08.012.

4. H. S. Michael and A. P. Nicholas, Chronobiology, drug delivery and chronotherapeutics, Adv. Drug Del. Rev. 59 (2007) 828-851; DOI: 10.1016/j.addr.2007.07.001.

5. A. S. Mandal, N. Biswas, K. M. Karim, A. Guha, S. Chatterjee, M. Behera and K. Kuotsn, Drug delivery system based on chronobiology-A review, J. Control. Release 147 (2010) 314-325; DOI: 10.1016/j.jconrel.2010.07.122.

6. B. C. Youan, Chronopharmaceutics: gimmick or clinically relevant approach to drug delivery? J. Control. Release 98 (2004) 337-353; DOI: 10.1016/j.jconrel.2004.05.015.

7. United States Pharmacopoeia 30, National Formulary 24, The United States Pharmacopoeial Convention, Rockville 2006, pp. 884-885.

8. V. I. Teberekidis and M. P. Sigalas, Theoretical study of hydrogen bond interactions of felodipine with polyvinylpyrrolidone and polyethyleglycol, J. Mol. Struc-THEOCHEM. 803 (2007) 29-38; DOI: 10.1016/j.theochem.2006.09.016.

9. M. Yasir, M. Asif, A. Kumar and A. Aggarval, Biopharmaceutical classification system: An account, Int. J. Pharm. Tech. Res. 2 (2010) 1681-1690.

10. B. Abrahamsson, D. Johansson, A. Torstensson and K. Wingstrand, Evaluation of solubilizers in the drug release testing of hydrophilic matrix extended-release tablets of felodipine, Pharm. Res. 11 (1994) 1093-1097.

11. A. T. M. Serajuddin, Solid dispersion of poorly water-soluble drugs: Early promises, subsequent problems, and recent breakthroughs, J. Pharm. Sci. 88 (1999) 1058-1066.

12. D. M. Bramhane, N. S. Saindane and P. R. Vavia, Inclusion complexation of weakly acidic NSAID with $\beta$-cyclodextrin: selection of arginine, an amino acid, as a novel ternary component, J. Incl. Phenom. Macro. 69 (2010) 453-460. 
K. P. Pagar and P. R. Vavia: Felodipine $\beta$-cyclodextrin complex as an active core for time delayed chronotherapeutic treatment of hypertension, Acta Pharm. 62 (2012) 395-410.

13. J. Mielcarek, A. Czernielewska and B. Czarczynska, Inclusion complexes of felodipine and amlodipine with methyl- $\beta$-cyclodextrin, J. Incl. Phenom. Macro. 54 (2006) 17-21.

14. M. E. Brewster and T. Loftsson, Cyclodextrins as pharmaceutical solubilizers, Adv. Drug Del. Rev. 59 (2007) 645-666.

15. E. Karavas, E. Georgarakis and D. Bikiaris, Application of PVP/HPMC miscible blends with enhanced mucoadhesive properties for adjusting drug release in predictable pulsatile chronotherapeutics, Eur. J. Pharm. Biopharm. 64 (2006) 115-126.

16. L. M. Prisant, Hypertension and chronotherapy: Shifting the treatment paradigm, Am. J. Hypertens. 14 (2001) 277S-279S.

17. E. Karavas, E. Georgarakis and D. Bikiaris, Felodipine nanodispersions as active core for predictable pulsatile chronotherapeutics using PVP/HPMC blends as coating layer, Int. J. Pharm. 313 (2006) 189-197.

18. T. Higuchi and K. A. Connors, Phase-solubility Techniques, in Advances in Analytical Chemistry and Instrumentation, Wiley Interscience Publisher, New York 1965, pp. 117-212.

19. E. Karavas, E. Georgarakis, M. P. Sigalas, K. Avgoustakis and D. Bikiaris, Investigation of the release mechanism of a sparingly water-soluble drug from solid dispersions in hydrophobic carriers based on physical state of drug, particle size distribution and drug-polymer interactions, Eur. J. Pharm. Biopharm. 66 (2007) 334-347; DOI: 10.1016/j.ejpb.2006.11.020.

20. M. N. Reddy, T. Rehana, S. Ramakrishna, K. P. R. Chowdary and P. V. Diwan, $\beta$-cyclodextrincomplexes of celecoxib: Molecular-modeling, characterization, and dissolution studies, AAPS Pharm Sci. 6 (2004) 1-9; DOI: 10.1208/ps060107.

21. C. H. Marques, J. Hadgraft and I. Kellaway, Studies of cyclodextrin inclusion complexes. I. The salbutamol-cyclodextrin complex as studied by phase solubility and DSC, Int. J. Pharm. 63 (1990) 259-266; DOI: 10.1016/0378-5173(90)90132-N.

22. S. Suresh, H. N. Shivakumar and G. K. Kumar, Effect of $\beta$-cyclodextrin complexation on the solubility and dissolution rate of carbamazepine from tablets, Ind. J. Pharm. Sci. 68 (2006) 301-307; DOI: $10.4103 / 0250-474 X .26657$.

23. F. F. Eugene and A. H. Timothy, Pre-formulation, in The Theory and Practice of Industrial Pharmacy (Eds. L. Lachmann, H. A. Liberman and J. L. Kanig), 3rd ed., Varghese Publishing House, Mumbai 1987 , p. 171

24. K. Amareshwar and D. K. Rai, Spectroscopic studies of some antidiabetic drugs, Spectrochim. Acta 59 (2003) 1673-1680; DOI: 10.1016/S1386-1425(02)00405-5.

25. I. Bratu, F. Veiga, C. Fernandes, A. Hernanz and J. M. Gavira, Infrared spectroscopic study of triacetyl- $\beta$-cyclodextrin and its inclusion complex with nicardipine, Spectroscopy 18 (2004) 459-467; DOI: 10.1155/2004/727869.

\author{
$S A Z \check{E T A K}$
}

\title{
Kompleks felodipina s $\beta$-ciklodekstrinom kao aktivnom ovojnicom za vremenski odgođenu terapiju hipertenzije
}

KUNAL P. PAGAR i PRADEEP R. VAVIA

U radu je opisan razvoj kronoterapijskog pripravka felodipina (FD) za brzo oslobađanje ljekovite tvari nakon određenog vremenskog razdoblja u liječenju hipertenzije. U tom pripravku FD kompleks sa ciklodekstrinom (ljekovita tvar) obavijen je slojem koji 
K. P. Pagar and P. R. Vavia: Felodipine $\beta$-cyclodextrin complex as an active core for time delayed chronotherapeutic treatment of hypertension, Acta Pharm. 62 (2012) 395-410.

bubri i obložen etilcelulozom (netopljivi vodopropusni polimer). Oslobađanje iz FD kompleksa tri puta je povećano u odnosu na oslobađanje čistog FD. Povećanje količine i brzine oslobađanja posljedica je amorfizacije felodipina, što se pokazalo pomoću XRD, DSC i SEM. FTIR i ${ }^{1} \mathrm{H}$ NMR studije potvrdile su na temelju vodikovih veza da je stvoren kompleks između FD i ciklodekstrina. Oslobađanje felodipina podešeno je pomoću pH neovisnog polimera, tj. pomoću etilceluloze, te dibutil ftalata kao plastifikatora. Proučavan je utjecaj formulacijskih varijabli kao što su viskoznost polimera, koncentracija plastifikatora i superdezintegranta u sloju koji bubri te debljina obložnog sloja na vrijeme odgode početka oslobađanja. U vodenoj sredini obložni sloj bubri i puca, nakon čega se lijek brzo oslobađa. U dobivenim pripravcima vrijeme odgode početka oslobađanja bilo je 5-7 h, što je pogodno za kronoterapijsku primjenu.

Ključne riječi: felodipin, $\beta$-ciklodekstrin, kronoterapijski sustav, etilceluloza

Department of Pharmaceutical Sciences and Technology, Institute of Chemical Technology, Mumbai, India 